International Journal of Linguistics, Literature and Translation (IJLLT)

ISSN: 2617-0299 (Online); ISSN: 2708-0099 (Print)

DOI: $10.32996 / \mathrm{ijllt}$

Journal Homepage: www.al-kindipublisher.com/index.php/ijllt

IJLLT

\title{
Dream in Disguise: A Marxist Analysis of Presentation of Dream in Paulo Coelho's The Alchemist
}

Tanmoy Mazumder

Assistant Professor, Department of English, Jashore University of Science and Technology, Jashore, Bangladesh

Corresponding Author: Tanmoy Mazumder, E-mail: tanmoy_eng@just.edu.bd

\section{ARTICLE INFORMATION}

Received: November 25, 2020

Accepted: January 18, 2021

Volume: 4

Issue: 1

DOI: $10.32996 /$ ijllt.2021.4.1.23

\section{KEYWORDS}

American dream, capitalist ideology, dream metaphor, marxist analysis, rugged individualism, santiago's quest

\section{ABSTRACT}

This study investigates Paulo Coelho's highly popular novel, The Alchemist (1988), in its English translation. Coelho's The Alchemist has positively influenced millions of its readers worldwide as it inspires them to pursue their dreams or their "personal legends" in their lives without being afraid of failure. Santiago's quest for his dream becomes a motivation for the readers to face challenges in their road to success in life. Coelho himself advocates for being aware of our "personal calling" which he says is "God's blessing" or, "our own dream". The current research questions the presentation of this dream by the author in this novel as it does not seem to be a simple dream. The dream is regarded as a metaphor not only by the author himself, but also by many critics who interpret this dream from a positivistic outlook to life. In this research, I would argue that this dream has its other metaphorical connotations too due to its way of presentation. Santiago's dream and its pursuit highly resemble the pursuit of American Dream, a capitalist ideology. Santiago's quest for his dream and the hidden treasure which he finds in the end has been argued as promotion of "rugged individualism" in this study. Thus, the paper, from a Marxist point of view, decodes the dream metaphor in The Alchemist, and tries to understand the operation of other capitalist ideologies in it.

\section{Introduction}

In its $71^{\text {st }}$ impression of Paulo Coelho's The Alchemist, HarperCollinsPublishers, on the top of the cover page of the novel, notes that 65 million copies of this novel have been sold, which is something exceptional and truly amazing for any author for a single text. The immense popularity of this novel lies in its subject matter primarily, which depicts a tale of a teenage boy's extraordinary achievement and fulfillment of his dream. As popular American singer Madonna says of it, "A beautiful book about magic, dreams and the treasures we seek elsewhere and then find on our doorstep". (Back Cover, The Alchemist). The novel tells us the story of a teenager named Santiago from the Andalusian region of Spain who defies his parents' desire of him to become a clergy and settle down in his comfortable home environment of which he (Santiago's father) confidently says that "our countryside is the best, and our women the most beautiful." (Coelho, 2016, p. 9). Santiago, thus, becomes a shepherd and travels around the region of Andalusia with his flock of sheep. A recurring dream, in which a child tells him to find out a treasure hidden at the foot of the Egyptian pyramids, troubles him immensely. Eventually, Santiago, motivated by a magical and mysterious old man named Melchizedek, sells his herd of sheep and sets out for the Egyptian pyramids to find out the treasure. Crossing the narrow strait of Gibralter he reaches Tangier where he is cheated and robbed by a stranger. Being frustrated, Santiago decides to get back to Andalusia and become a shepherd again. He takes a job in a local merchant shop and helps him (the merchant) to improve a lot in the business. Thus, in a year he gets enough money to go back to Spain and buy a flock of sheep again. However, he changes his mind and starts his journey to the pyramids once more. The journey is a perilous one: he faces a lot of challenges on the road to the pyramids. To avoid tribal conflicts in the desert, the party with whom he travels through the deserts takes rest at an oasis called Al-Fayoum where Santiago meets a young Arab girl named Fatima. They fall in love with each other. Santiago, also, meets an alchemist in this place who teaches him many things that Santiago never knew before. Santiago is then accompanied by the alchemist in his journey through the desert and after facing different troubles, they reach a Coptic monastery from where Santiago must travel alone. Santiago, finally reaches the pyramids and when he starts digging for

K. C AL-KINDI CENTER R D FOR RESEARCH AND R. D DEVELOPMENT Your gateway to world-class research

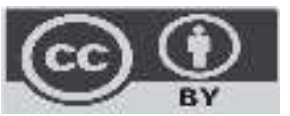

Published by Al-Kindi Center for Research and Development. Copyright (c) the author(s). This open access article is distributed under a Creative Commons Attribution (CC-BY) 4.0 license 
treasures at the feet of the pyramids, he is captured and beaten by two men. When Santiago speaks to them about his purpose and his dream, they leave him thinking that he has nothing to offer. One of them tells him not to follow this kind of hollow dream as he himself gets a dream often, a dream that tells of a treasure hidden under a Sycamore tree in a ruined church in the Andalusian region. This is the same place where Santiago got his dream. Santiago returns to Andalusia, goes to that church and finds the hidden treasure there. Getting rich, he decides to return to Fatima.

This tale has become a metaphor of our dreams in life, which we fail to understand and even if we assume it, most of us dare not to pursue it. Sonia Soni in her paper, "Life Realized through Riddles: A Study of Paulo Coelho's The Alchemist", asserts, "The subtitle of the novel A Fable Following Your Dream, The Alchemist explains how omens, which generates from the Soul of the World, can guide us in the pursuit of our dream." (Soni, p. 88). And, this seems quite correct as we see that the book has been translated in at least 61 languages worldwide and this huge success has its reason rooted in its vision, as said by Coelho himself in the Author's Note of his novel:

... "What's the secret behind such a huge success?" The only honest response is that I don't know. All I know is that, like Santiago the shepherd boy, we all need to be aware of our personal calling. What is personal calling? It is God's blessing, it is the path that God chose for you here on Earth. Whenever we do something that fills us with enthusiasm, we are following our legend. However, we don't all have the courage to confront our own dream." (Coelho, 2016, pp. vii-viii).

This research tries to understand this metaphor of Santiago's dream and its presentation in this novel from a different perspective. Even after accepting the apparent positive impact of the dream metaphor in The Alchemist and the appreciation of celebrities all around the world, I would point out towards an important possible flaw in this novel. The novel seems to be passively promoting capitalist ideologies as we see the dream metaphor presented in this novel resembles the ideology of American Dream and Santiago's adventurous quest for the treasure and his success can be argued as a promotion of the beliefs of rugged individualism. Lois Tyson (2011) says:

Yes, there are literary works that, whether they intend to or not, reinforce capitalist or classist ideologies .... And, in such cases we would use concepts from Marxist theory to expose this flaw in the work in question, for from a Marxist perspective this aspect of the literary text would be a flaw. (p. 133).

The concept of American Dream and rugged individualism, in this study, will be used as globalized model of capitalist beliefs rather than in the American context. In the twenty first century, America is the ideal for all capitalist ideologues, the concepts of American dream can no more merely refer to America. In contrary, it has become a global concept of capitalism. Again, this research uses American publishing house HarperCollinsPublishers' English translation of the original novel, first published in Brazil in Portuguese in 1988.

So, this dream metaphor becomes a research problem in this novel as, whether the author intends to or not, it has high affinity with capitalist ideologies to call it a noble dream. As Marxist critics "make a division between the 'overt' (manifest or surface) and 'covert' (latent or hidden) content of a literary work" and then "relate the covert subject matter of the literary work to basic Marxist themes" (Barry, 2013, p. 161), this paper seeks to analyze the hidden capitalist ideologies in this text. Thus, this study sets it objectives: firstly, to probe Coelho's presentation of dream in The Alchemist and find out to what extent it can be called an indirect propagation of the ideology of American Dream; secondly, to analyze Santiago's adventurous quest for the hidden treasure and his success and understand whether or not it becomes a celebration of rugged individualism. This qualitative research, thus, investigates Paulo Coelho's The Alchemist from a Marxist critical perspective and argues that the presentation of dream and Santiago's consequent quest for the treasure in the text has its flaws as it passively promotes capitalist ideologies; the dream metaphor seems to be capable of propagating American Dream, while Santiago's adventurous journey in quest for the treasure is a triumph of rugged individualism.

\section{Theoretical and Conceptual Framework}

This research has a clear and concise theoretical point of view that works as its framework. As the paper intends to trace operations of capitalist ideologies in The Alchemist, it is obvious that Marxist critical theory will be its sole analytical tool. Marxism, as a non-repressive ideology, tries to unveil ideologies that are repressive for human beings and that often works to keep us blind to the existing repressive power structure in the society. This study focuses on two specific capitalist ideologiesthe American Dream and Rugged Individualism.

Now, the American dream is a "capitalist ideology associated specifically with American history and culture." (Tyson, 2011, p. 115). As per this ideology, "anyone who has the determination to work hard enough and the persistence to work long enough can rise from "rags to riches" as America is the land of equal opportunity." (Tyson, 2011, p. 115). Marxism contests this belief and points out that American Dream blinds us to the facts that in reality most people do not get equal opportunity in their basic 
needs like education, housing, employment etc., because there are discriminations based on socio-economic class, race, gender etc. In this paper, the concept of American Dream has not been used in the literal context of America, rather it has been applied to a dominant globalized form of capitalist ideology. Thus, American Dream in this paper is rather a globalized American Dream. We can even call it a Brazilian Dream as Paulo Coelho, the author, is a Brazilian and Brazil in many ways is the new America in the world now. We can also call it a Spanish American Dream as our hero, Santiago has been portrayed as a Spanish teenager in the novel. So, with a view to decoding the dream metaphor and addressing the capitalist beliefs conveyed in The Alchemist, this paper uses the term American Dream.

Rugged individualism is another capitalist ideology closely connected to American Dream and it "holds up for our admiration the example of the individual who strikes out alone in pursuit of a goal not easily achieved" (Tyson, 2011, p. 115). For example, it celebrates the objective of "undertaking an untried, high-risk line of business, in which one could lose all one's money, or rushing for gold on the American frontier, in which attempt one could lose one's life." (Tyson, 2011, p. 115). Marxism criticizes this idea by pointing out that it has been romanticized by American folklore and, in reality, it requires putting self-interest above community interest. In this research, this concept of rugged individualism will be discussed in the context of Santiago's quest for his dream and the treasure. It will be applied as a twentieth century global capitalist ideological concept.

\section{Rethinking the Dream Metaphor: The American Dream in The Alchemist}

Coelho's presentation of dream in The Alchemist has its connotations. The author justifies it as a fable about following our dream. Critics take it in such ways like "A Journey Towards Self Actualization" (Baba \& Raina, 2018); "A Quest for the Fulfillment of Destiny" (Manogna et al., 2018); "Life Realized through Riddles" (Soni, 2014) etc. Thus, most of the critical approach to this text is somehow on line with what the novelist himself prescribes it to be understood. I would like to point out that a text has its meaning independent of the author's intention. Tyson points out to the concept of "The death of the author" in this regard. She says-

In the early decades of the twentieth century, students of literature were taught that the author was our primary concern in reading a literary work: ... which is called authorial intention. Our focus has changed over the years to the point that ... the author is no longer considered a meaningful object of analysis. We focus, instead on the reader; on the ideological, rhetorical, or aesthetic structure of the text .... (Tyson, 2006, p. 2).

Coelho's The Alchemist can be analyzed from this independent perspective too. Firstly, I would point out towards the background of Santiago as portrayed in this novel; then, Santiago's experiencing the dream would be analyzed; after that, the paper will investigate how the dream has been pushed forward and romanticized in this text; finally, I would argue that the dream has been "commodified" in this novel and the way it has been presented becomes an indirect promotion of American Dream.

Portrayal of Santiago's background in The Alchemist fits well for the propagation of capitalist ideologies. He has been introduced in humble settings: a teenager with simple desires in a simple life. He feels for his sheep and he is, somehow, in love with a young woman in a nearby city. Santiago's job requires him to constantly move on with his sheep. It is a quite romantic one, but it often makes him lonely sometimes. The readers understand that Santiago loves his freedom, though part of his mind wants to settle down in life and create healthier connections with people in his surroundings. If we look back at his choosing this profession, we will see that Santiago, who attended a local seminary school till sixteen years of age, revolted against his family desire of making him a fine priest and became a shepherd.

His parents had wanted him to become a priest, and thereby a source of pride for a simple farm family. ... He studied Latin, Spanish, and theology. But ever since he had been a child, he had wanted to know the world .... One afternoon, on a visit to his family, he had summoned up the courage to tell his father that he didn't want to become a priest. That he wanted to travel. (Coelho, 2016, p. 8).

This context of Santiago then builds the whole idea of the text where we see Santiago pushing on further in his ambition. Santiago, here, can be seen as a person with ambition different to his parents and his community. He is different as he can think different. This makes him an ideal character to pursue difficult things in life. In capitalist beliefs like American Dream "success can be achieved ... merely through initiative and hard work" (Tyson, 2006, p. 61) and in our hero we find this initiative through his willingness to attempt different things in life.

Santiago's initial experience of the dream can be understood differently. The dream is significant in its context. Santiago experiences the dream for the second time when he takes rest with his sheep under that sycamore tree in that ruined church. 
This dream should be analyzed in connection to not only his present situation in life, but also his earlier desire in life. His present situation in life shows a stagnant condition in life which is stuck to the flock of sheep. In these two years with the sheep, he has become familiar with the Andalusian region, and this contradicts to his earlier desire for change in life and strive for something more. The young daughter of the merchant in Tarifa and Santiago's desire for her symbolizes a change in life, though that change is synonymous to what he refused earlier in life- stability and contentment in life. So, the dream has been introduced in this novel as a motto of "never settle" (a slogan used by the smartphone brand OnePlus) in life for the protagonist. And, desire for more material achievement is a fundamental belief of present-day capitalist world.

Santiago's dream has been romanticized and pushed forward in such a way that syncs with the motto of capitalist tenets. The author promotes the terms "personal calling", "God's blessing", "one's own legend", "our own dream" etc. in this novel, in the author's note section. These terms romanticize the whole concept of dream in this text, though the things that these terms refer to are not innocent "something that fills us with enthusiasm" (Coelho, 2016, p. viii) as the novelist says. They also focus on individualism. And, individualism in life is not always a cherishing thing as it is often associated with self-interest and competition. Marxist theory disapproves it as "it tends to ensure that the most selfish, unethical people will rise to the top, as they are the ones willing to do whatever it takes to win" (Tyson, 2011, p. 114) and it "emphasizes the importance of the individual- "me, me, me"- instead of the group" (Tyson, 2011, p. 114). In Santiago's case, his dream may not be propagating competition but promoting individualism surely. The text brings about the dream as an individual goal and then, pushes it forward by "commodifying" it. The hidden treasure associated with Santiago's dream makes it a commodity, a thing that has a material value. In Marxist belief, value of a commodity depends not in "what it can do (use value) but in the money or other commodities for which it can be traded (exchange value) or in the social status it confers on its owner (sign exchange value)" (Tyson, 2006, p. 62). The dream in The Alchemist has both its exchange value and sign exchange value as we can see Santiago gets the hidden treasure by pursuing the dream and his honour as a new alchemist among the Arab people in Al Fayoum and to the war like tribal leader comes out of his pursue of this dream that makes him wise too. Zindi Nabila Onedani and Danu Wahyono (2018) in their paper, "SANTIAGO'S WAY TO FIND HAPPINESS IN PAULO COELHO'S THE ALCHEMIST", discuss the dream in The Alchemist:

The dream leads him into a meaningful journey that teach him about strife to realize his dream and to find his happiness. On the journey, he meets a lot of people that teaches about life, love and many things. But he gets something more important than just a treasure trove in the end. He finds his happiness. (p. 62).

Here, the authors interpret the dream as Santiago's way to find happiness in life. It teaches him about life and love. But, the dream metaphor has its capitalist connotation too. As American Dream propagates that "anyone who has the determination to work hard enough and the persistence to work long enough can rise from "rags to riches"" (Tyson, 2011, p. 115). It requires ambition and the desire and persistence to fulfill that ambition through hard work. This thing in the dream metaphor in The Alchemist is very evident. As we have seen in earlier discussion that Santiago has been portrayed as a boy from a humble family background who "worked hard just to have food and water, like the sheep" (Coelho, 2016, p. 8). Santiago gets out from his humble background and buys a flock of sheep and becomes a shepherd. All is fine until he gets the dream which tells him of the hidden treasure. This unsettles him and later he is instigated to pursue his dream by a mysterious person who calls himself King of Salem. This can be interpreted as Santiago's latent ambition of becoming different and becoming rich in life. I will not consider the explanation that "it deals with the expedition of Santiago in literal, symbolic, intellectual and spiritual level" (Baba and Raina, p. 145). Santiago's dream has a clear material urge: the urge to become rich, the call to change one's fate through gaining material wealth. In the end, Santiago, by responding to that call, becomes successful as he gets the promised treasure, though not in the feet of the pyramids but in the feet of that Sycamore tree in the ruined church.

The boy smiled, and continued digging. Half an hour later, his shovel hit something solid. An hour later, he had before him a chest of Spanish gold coins. There were also precious stones, gold masks adorned with red and white feathers, and stone statues embedded with jewels. (Coelho, 2016, p. 160).

Santiago returning from the pyramids to the ruined church for the hidden treasure and getting it out for him is a strong evidence of the 'covert' capitalist ideology propagated in this novel. Santiago's American dream becomes a success. He gets rich and, then, leaves for Fatima, his Arab beloved. This somehow substantiates one of the beliefs of American Dream: you get rich, you get your girl. Again, the Gypsy woman's condition of giving her one-tenth of the treasure and Santiago remembering "that he had to get to Tarifa so he could give one-tenth of his treasure to the Gypsy woman, as he promised" (Coelho, 2016, p. 160) seems like a capitalist businessman's promise to his partner. If the treasure Santiago found through this dream has been solely 
spiritual awakening and wisdom, then the novelist could have rethought the ending of the novel. The ending has a clear materialist capitalist connotation of the dream metaphor.

\section{Celebration of Rugged Individualism}

Santiago's quest for the treasure of his dream is rich with metaphors. Manogna et al. (2018) in their paper, "A Quest for the Fulfillment of Destiny: A study on Santiago in Paulo Coelho's "Alchemist." suggests "The experiences of the boy reveal that life is generous to those who pursue their destiny. And it gives us the inspiration to follow our dreams by seeing the world through our own eyes and not someone else's." (Manogna et. al., 2018). Baba and Raina (2018) in their article, "THE ALCHEMIST: A JOURNEY TOWARDS SELF-ACTUALIZATION" assumes that this novel is "one such tale that encourages and inspires readers to realize their potential by constantly working on the impulses of the soul" and thus, attempt to analyze Santiago's self-discovery as the microcosm, representing the journey of everyman towards self-actualization. (Abstract). Terrence Musanga (2009) in his article, "The Journey Motif and the Search for Life's Meaning in Paulo Coelho's The Alchemist (1988)" opines that "The cyclic journey of Santiago is also a process of self discovery and self integration. It is also about the need to maintain balance and harmony in Santiago's life." (p. 105). The problem with these arguments is not that they discuss the spirituality related with the dream, rather they fail to address the capitalist ideological motivation that this novel may push passively among its readers. Thus, this research would like to point out that Santiago's journey in quest for the treasure metaphorically celebrates certain capitalist ideology too. In the following passage, the paper would analyze how Santiago's adventurous journey falls in the category of rugged individualism.

Presentation of Santiago's motivation and the quest he takes overcoming all the obstacles he faces celebrates the capability of a determined individual to pursue his goal. This is called rugged individualism in Marxist criticism. Marxism considers rugged individualism as a key concept of capitalist ideology and discusses it along with the concept of American Dream. Rugged individualism "holds up for our admiration the example of the individual who strikes out alone in pursuit of a goal not easily achieved" (Tyson, 2011, p. 115). A rugged individualist "believes that his first duty is to himself and his first goal is to win whatever competition he's entered" (Tyson, 2011, p. 115). Santiago's quest for the treasure can be discussed from this critical perspective too. Santiago gets a recurring dream: a dream where a little boy talks about his gaining a hidden treasure if he goes to the pyramids in Egypt. Now, this dream, as discussed in the previous chapter, has a clear connotation for American Dream. Santiago eventually is motivated for the quest. He sells his dear flock of sheep which were his sole source of living as a shepherd. So, Santiago takes a huge risk- a risk that can ruin him like a game of dice. This willingness to take risk is very much like businesses in high capitalist world where bigger goals are set to achieve and bigger risks are associated with it. Santiago faces a dicey situation in his life but as his goal is a bigger achievement (the treasure is surely the biggest thing he can achieve), he is determined for it. His next experiences similarly confirm the features of rugged individualism. He is deceived by a fraud in Tangier; all his capital is gone. This happens in business. He took a big risk and loses all. But then, his determination is exceptional. He works hard in the crystal merchant's shop to regain most of his capital, so that he can go back to Andalusia and raise another flock of sheep. This shows his apparent loss of his determination for the ultimate goal, the hidden treasure. His innovative ability in the merchant's shop, his innate skill to make business successful is evident in his success in the crystal merchant's shop. He, then, does not return to Spain, rather resumes his pursue of the hidden treasure. All the difficulties, hardship, and challenges he faces on his way are suggestive of difficulties and challenges an individual can face in pursuing something big in the capitalist world. A rugged individual is he who comes out successful out of all these challenges. Thus, Santiago becomes a rugged individual who in the end shrugs off all the difficulties and reaches his goal, not just the pyramids, rather the hidden treasure. Santiago becomes an example of how a determined individual can achieve his difficult goal even after setting out alone. This story of success, somehow, seems quite similar to many stories of success in the capitalist world like the stories of Bill Gates, Oprah Winfrey, Howard Schultz, J. K. Rowling etc. as cnbc.com says:

You don't have to be born with a silver spoon in your mouth to achieve great things in life - though it certainly helps. Still, many of today's billionaires had very humble beginnings. Growing up poor didn't stop these CEOs, celebrities and business experts from reaching the pinnacle of success - and it shouldn't stop you, either. (cnbc.com)

\section{Conclusion and Suggestions for Future Research}

To sum up, it can be said that the paper tries to bring out the possible other meanings (aligned to capitalist beliefs) of the dream metaphor presented and celebrated (by the author, most of the readers and many celebrities) in The Alchemist. This does not discard all the positive intention and inspiration promoted by this novel and the novelist. Rather, this research desires to foreground the capitalist ideologies that operate in this text with a view to showing that a literary text does not always solely mean what it explicitly propagates. As twenty first century is a fertile ground for critical theories and the intention of the author is 
not of much importance due to the readers' freedom of perception and texts becoming independent entity, it is important to understand operations of all the possible meanings a text can have, especially, the ideological meanings. Marxism, in literature, tries to bring out the operations and propagations of capitalist ideologies (as it considers capitalism a repressive ideology) that operate in texts both overtly and covertly. In this study, the operations of capitalist ideologies like American Dream and rugged individualism have been discussed from a global perspective. These two capitalist ideologies have been argued to be of global importance as they no more merely operate in the American context as the world is a global village now and America is the centre of the capitalist world. So, the story involving an Andalusian boy can have global implication among its global readers. Again, we have to keep in mind that the novel The Alchemist reached the peak of its popularity only after being translated in English and promoted by American publishing houses, which is a clear example of its popularity in the capitalist haven of the world.

The paper has argued that the presentation of dream in this novel has its flaw as it, somehow, promotes capitalist ideology like American Dream. The goal of material gain set out for Santiago to achieve in this novel and Santiago getting it in the end can passively promote beliefs of American Dream. The inspirational spiritual achievement of Santiago has been overshadowed by his act of digging out the treasure in the end of the novel. Again, Santiago's journey in quest of the treasure has been argued as a celebration of rugged individualism in this research. Santiago's individuality has been foregrounded more in the text, which often resembles a rugged individual who sets out alone in pursuit of a hard thing in life and achieves it in the end through hard work and determination.

This study has its limitations. As it is a qualitative study, it focuses on textual analysis based on Marxist theoretical perspective. It would have been more interesting if responses from readers of various backgrounds could have been interviewed of about their perception of this text. Again, the research is based on the English translation of the original one written in Portuguese. The researcher will recommend taking up more researches on issues like the cultural impact of this dream metaphor and how this dream metaphor is influenced by the rise of Brazil, the author's home country, as a new capitalist harbour in the world.

\section{About the Author}

Tanmoy Mazumder has been working as an Assistant Professor in the Department of English, Jashore University of Science and Technology, Jashore 7408, Bangladesh. He has obtained his BA (Hons.) and Master's degrees from the Department of English, Jahangirnagar University. His area of interest includes Comparative Literature, Critical Theory, and Popular and Postmodern fiction. He can be reached at- Email: tanmoy_eng@just.edu.bd

\section{References}

[1] Baba, T. I. \& Raina, J. A. (2018). The Alchemist: a Journey towards Self-Actualization. International Journal of Interdisciplinary Research in Arts and Humanities, 3(1), 144-145. https://www.researchgate.net/publication/340261385_The_Alchemist_A_Journey_Towards_Self-actualization

[2] Barry, P. (2013). Beginning Theory. $3^{\text {rd }}$ ed., Viva Books.

[3] Coelho, P. (2016). The Alchemist. $71^{\text {st }}$ impression, HarperCollinsPublishers.

[4] Manogna, M. L., Charyulu, Dr. G. M. \& Kumar, Dr. G. K. (2018). The quest for the fulfillment of Destiny: A study on Santiago in Paulo Coelho's "Alchemist.". International Journal of Computer Engineering in Research Trends, 5(1), 1-3. DOI:10.22362/ijcert/2018/v5/i1/V5I101

[5] Musanga, T. (2009). The Journey Motif and the Search for Life's Meaning in Paulo Coelho's The Alchemist (1988). Unisa Latin American Report, 1(2), 100-110. https://www.researchgate.net/publication/305488763_The_Journey_Motif_and_the_ Search_for_Life\%27s_Meaning_in_Paulo_Coelho\%27s_The_Alchemist_1988

[6] Onedani, Z. N. \& Wahyono, D. (2018). Santiago's Way to Find Happiness in Paulo Coelho's The Alchemist. Anaphora: Journal of Language, Literary, and Cultural Studies, 1(2), 61-68. DOI: 10.30996/anaphora.v1i2.2091

[7] Soni, S. (2014). Life Realized through Riddles: A Study of Paulo Coelho's The Alchemist. MIT International Journal of English Language \& Literature, 1(2), 85-91. <http://www.mitpublications.org/yellow_images/1411556782_logo_paper15.pdf>

[8] Tyson, L. (2006). Critical Theory Today. $2^{\text {nd }}$ ed., Routledge.

[9] Tyson, L. (2011). Using Critical Theory. $2^{\text {nd }}$ ed., Routledge.

[10] <https://www.cnbc.com/2017/09/11/10-billionaires-who-grew-up-dirt-poor.html> accessed 30 December 2020. 